\title{
Abstracts of Papers Presented at the 2018 Annual Meeting
}

\author{
SESSION 1: LONG-RUN PERSPECTIVES ON CONFLICTS
}

Trust Unraveled: The Long Shadow of the Spanish Civil War

The Spanish Civil War (1936-1939) was one of the most devastating conflicts of the twentieth century, yet little is known about its long-term legacy. In this project we show that the war had a significant long-lasting effect on social capital, using geo-located data on historical mass graves and disaggregated modern-day survey data on trust. Preliminary results neither show a positive nor a significant effect of overall conflict on generalized trust. However, there is a significant negative relationship between exhumed mass graves and this same trust variable, pointing towards the deleterious long-term effects of political violence against civilians. To deal with the potential endogeneity of conflict, we use military plans of attack in conjunction with the historical (1931) highway network. We further decompose trust, finding negative effects of conflict on trust on institutions associated with the Civil War, but no effects when looking at trust on democratic institutions.

Felipe Valencia Caicedo, University of British Columbia, and Ana Tur-Prats, Universitat Pompeu Fabra

\section{Historical Violence and China's Missing Women}

Building on Marvin Harris' hypothesis that warfare was an important driver of gender inequality in human history, we investigate the impact of historical violence on contemporary sex ratios in China. We first apply cross-sectional OLS and IV analyses to show that juvenile sex ratios are more skewed in Chinese counties that border the Great Wall, which approximates China's nomadic-sedentary ecological divide, and counties that were home to communities that participated in piracy or commoner rebellions during the Qing dynasty (1644-1912). To uncover the transmission mechanism, we further conduct a survey experiment using violence-oriented prime stimuli. Upon receiving violence-oriented priming, the likelihood to express a preference for male offspring increases for participants born in historically violent cities, both absolutely and relative to participants born elsewhere. We interpret the finding as evidence that the observed persistent impact of historical violence on sex ratio is effected through the cultural (decision-making heuristics) channel. 


\section{Mandala Matters: Former Tributary States and Modern Civil Conflict in Thailand}

Thailand's former governance structure, known as a mandala system, defined an area's strength of relationship with the center, Bangkok, and outlying tributary polities based on its geographic proximity to both. Using novel civil conflict data covering 1970-2015, we find that long after the abolishment of the mandala system in the nineteenth century, proximity to a former tributary state continues to be associated with a strong local identity and higher levels of separatist violence today, controlling for distance to the state capital, borders, and other geographic and socio-economic factors.

Christopher Paik, New York University Abu Dhabi, and Jessica Vechbanyongratana, Chulalongkorn University

\section{SESSION 2: BANKING}

\section{Banking on the Boom, Tripped by the Bust: Banks, and the World War I Agricultural Price Shock}

Bank lending booms and asset price booms are often intertwined. Although a fundamental shock might trigger an asset boom, aggressive lending can push asset prices higher, leading to more lending, and so on. Such a dynamic seems to have characterized the agricultural land boom surrounding World War I. This paper examines (i) how banks responded to the asset price boom and how they were affected by the bust; (ii) how various banking regulations and policies influenced those effects; and (iii) how bank lending contributed to rising farm land values in the boom, and how bank closures contributed to falling prices in the bust. We find that rising crop prices encouraged bank entry and balance sheet expansion in agricultural counties. State deposit insurance systems amplified the impact of rising crop prices on the size and risk of bank portfolios, while higher minimum capital requirements dampened the effects. Further, increases in county farm land values were correlated with increases in bank loans during the boom. When farm land prices collapsed, banks that had responded most aggressively to the asset boom had a higher probability of closing, while counties with more bank closures experienced larger declines in land prices than can be explained by falling crop prices alone.

$$
\begin{array}{r}
\text { David WheElock, Federal Reserve Bank of St. Louis, } \\
\text { and MatTHEW JAREMSKI, Colgate University }
\end{array}
$$

The Effects of Banking Competition on Growth and Financial Stability: Evidence from the National Banking Era

How do restrictions on banking competition affect credit provision and economic output? And, how does it affect financial stability? To identify the causal effect of banking competition, we exploit a peculiarity of bank capital regulation in the National 
Banking Era: opening banks in towns with more than 6,000 inhabitants required twice the equity than in smaller towns, thus leading to a locally exogenous variation of entry costs and competition. We construct a novel comprehensive data set comprising the annual balance sheets of all national banks between 1867 and 1904, and link it with the results of the decennial census as well as data on railroad connections. We show that initially, cities with higher entry costs experienced lower loan growth and a slower expansion in their manufacturing industry. However, banks that face less competition are also more resilient during a major financial crisis, the Panic of 1893. Altogether, our evidence suggests that banking competition leads to economic growth in the mediumterm, but increases the risk financial instability. However, our evidence also suggests that the increase in financial instability and the number of bank failures does not necessarily affect real economic outcomes.

\section{Mark Carlson, Sergio Correia, and Stephan Luck,} Federal Reserve Board

\section{Working of the Banking Networks and Central Bank in Late 19th Century Japan}

We shed new light on the interaction between private banks and the central bank in nineteenth century Japan by focusing on the formation and working of networks of these banks. We employ a network analysis with branching and correspondence contracts among these banks. We also use bank lending rates at the prefectural level to test the effects of the networks on the integration of the national financial market. We find that private banks had already built a dense network throughout the nation before the establishment of the central bank, which contributed to the integration of the national financial market to some extent; the central bank contributed little or nothing to the integration of the financial market in its early days; and the central bank found another way to contribute, namely, by providing liquidity during the financial crisis of 1890 as a lender of last resort.

Masato Shizume, Waseda University

SESSION 3: INEQUALITY

\section{From Famine and Civil War to Welfare State: Income and Wealth Inequality in} Finland from 1865 to 2016

The evolution of long-term income and wealth inequality has received more attention in recent decades. Although a growing body of literature has investigated the impacts of economic shocks on inequality in the twentieth century, long-term studies on the effects of such shocks and the subsequent periods of recovery are still rare. This paper contributes to this discussion by presenting a new consistent series of before- and aftertax income and wealth inequality in Finland from 1865 to 2016. Furthermore, united 
distributions for income and wealth are presented, which are rare in the existing literature. The preliminary results indicate that the growth periods until after WWII were related to increasing inequality, whereas economic shocks decreased inequality (e.g., famine, civil war, depressions, WWI and WWII). However, this link disappeared with the advent of the welfare state: there was decreasing inequality from the 1960 s until the late 1980 s and increasing inequality until 2001.

Petri RoIKonen, University of Helsinki

\section{Formal Education, Practical Learning and Social Mobility in Scandinavia}

In Scandinavia, universities and technical schools had the tradition, between the 1820 s and the 1970s, of publishing biographies of graduates with detailed information about their life and work. This paper presents the project of formal education, practical learning and social mobility in Scandinavia, which includes making a database of these biographies to explore (1) the direct roles of formal education and practice for innovation and economic performance, and how this played out in different industries and (2) access to education and the historical impact of education on social mobility, and differences in this regard between genders and regions. I propose a systematic empirical historical investigation of formal and practical education processes, travels and career paths of entire high- and technical school cohorts in a period when these "catching-up" countries of the Industrial Revolution went through a radical transformation in terms of industrial and economic development.

KRISTIN RANESTAD, University of Oslo

\section{Inequality and Poor Law Policy in Late-Victorian England}

This paper introduces a new dataset of the provision of poor relief in England and Wales between 1860 and 1900, including both expenditure and the number of recipients of relief. Poor relief at this time was provided by a system of over 600 locally elected government bodies, providing a valuable setting to test different explanations for variation in welfare expenditure. A negative correlation is found between the generosity of poor relief policy, as deigned by allowing outdoor relief, and the share of middle class occupations in the workforce. The poor law data is then linked to a new measure of income inequality in urban parliamentary constituencies. Areas with higher inequality are found to have been more generous in offering poor relief. Possible explanations for these patterns are discussed.

Jonathan Chapman, New York University Abu Dhabi 
SESSION 4: PRE-INDUSTRIAL STANDARDS OF LIVING Economic Consequences of the Napoleonic Wars: Evidence from Market Integration
in Central Europe, c.1780-1830

We analyze the period of Germany's transition to the post-Malthusian era and exploit the Napoleonic Wars as a natural experiment. The hypothesis is that the entailed shift to unified tariff regimes and state formation led to integration of regional grain markets, which relieved food constraints for economic development. We analyze rye price gaps in a difference-in-differences framework and find a substantial and robust negative effect on bilateral price gaps in Bavaria. Price gaps were reduced by ca. 40 percent with regard to the pre-war level. The results do not support the view that French reforms were important for market integration.

\section{Hakon Albers, Martin-Luther University Halle, and Ulrich Pfister, University of Münster}

\section{The Shock of Modern Economic Growth: Clarifications on the Antebellum Puzzle}

Bodenhorn, Guinnane, and Mroz (2017) claim that early historical height data are unreliable because samples were typically self-selected rather than random. Accordingly, episodes of declining height are typically spurious artifacts of negative selection into the military during favorable labor market conditions. We study an example they discuss at some length, the Antebellum Puzzle in the United States, and find that neither the historical evidence nor indeed their own statistical analysis support their claims. The decline in physical stature in the decades before the Civil War was real.

Brian A’Hearn and John Komlos, University of Munich

All Equal in the Face of Death? Explaining Regional Differences in Wealth Inequality after the Black Death. The Case of Social Agro Systems in Rural Hainaut 1250-1500

Recent studies on wealth distribution in premodern Europe challenge us to rethink traditional theories on the drivers of inequality. In general, three new explanations have been put forward: demography, organization of production and the power of elites to create coercive institutions. Due to the still very limited amount of data, more empirical research is needed to test these hypotheses. This paper therefore employs new archival sources, namely mortmain accounts (i.e., death taxes) and manorial surveys, to retrace evolutions of wealth inequality within the county of Hainaut in the century and half after the Black Death. To determine the impact of demography, these sources are 
confronted with the trends found in ten hearth censuses covering the entire countryside. The explanatory power of production and institutions is tested through a comparative analysis of four sub regions, characterized by differing power relations, farming techniques, property rights and income strategies.

SAm GeEns, University of Antwerp, and Joris RoOsen, Utrecht University

SESSION 5: LABOR MARKETS

Organizing Collective Action: Labor Strife in the U.S. in the 1880 s

This paper explores the impact of American labor unions on strike outcomes from 1881 to 1886 . Unorganized workers were responsible for circa forty percent of industrial conflict during this period. We construct an instrument for union assistance from the location of the assemblies of the Knights of Labor. We estimate that organization increased the probability of success of a walkout by 31 percentage points from a baseline rate of 40 percent. The non-causal estimate is significantly lower at 12 percentage points. We argue that unionization benefited workers by helping them win strikes and allowing them to undertake more difficult strikes. Union executives deprecated industrial action, but they could not impose discipline on the rank on file, which may partly explain the collapse of the Knights of Labor after 1886. Organization reduced the probability of job loss as well. Despite higher payoffs ex ante, we find no effect on the payoff of successful walkouts

Luca Bittarello, Northwestern University

Closing Heaven's Door: Evidence from the 1920s U.S. Immigration Quota Acts

The introduction of immigration quotas in the 1920s fundamentally changed U.S. immigration policy. We exploit this policy change to estimate the economic consequences of immigration restrictions for the U.S. economy. The implementation of the quota system led to a long-lasting relative decline in population growth in areas with larger pre-existing immigrant communities of affected nationalities. This effect was largely driven by the policy-restricted supply of immigrants from quota-affected nationalities and lower fertility of first- and second-generation immigrant women. In the more affected areas labor productivity growth in manufacturing declined substantially and native workers were pushed into lower-wage occupations. While native white workers faced sizable earnings losses, black workers benefited from the quota system and improved their relative economic status within the more affected areas

Philipp Ager, University of Southern Denmark, and CASPER HANSEn, University of Copenhagen 
Fatherless: The Long-Term Effects of Losing a Father in the U.S. Civil War

We use the demographic shock of the U.S. Civil War to study the consequences of losing a father during childhood on long-term economic outcomes, as well as intergenerational effects on the grandchildren of the deceased soldiers. We link data from the universe of Union Army soldiers to the full-count United States. Census to identify fathers who fought in the war, before linking the 1860 Census to later Censuses, following the children and grandchildren of soldiers over time. We instrument a father's death probability by the casualty rate of his military unit, mainly determined by military strategy and not related to the socio-economic composition of units. We find that children whose father died in the Civil War are 14 percentage points less likely to have a high-skilled occupation and 28 percentage points less likely to have a semi-skilled occupation.

YanNick Dupraz and ANDy FerRaRa, University of Warwick

SESSION 6: ORIGINS OF SOCIETAL CONFLICT

Resistance to Institutions and Cultural Distance: Brigandage in Post-Unification Italy

We study how cultural distance affects the rejection of imposed institutions. To do so, we exploit the transplantation of Piedmontese institutions on Southern Italy that occurred during the Italian unification. We assemble a novel and unique dataset containing municipal-level information on episodes of brigandage, a form of violent uprising against the unitary government. We use the geographic distance from local settlements of Piedmontese descent as a proxy for the cultural distance between each municipality and the new rulers. We find robust evidence that cultural distance from the origins of the transplanted institutions is significantly associated with more intense resistance to these institutions. Our results further suggest that the rejection of the transplanted institutions may have a long-lasting effect on political participation.

\section{Giampaolo Lecce, Bocconi University, Laura Ogliari, University of Milan, and Tommaso Orlando, Banca d'Italia}

\section{The Origins of Disorder}

We seek to understand and explain the present shape of global divergence. First, we develop a new metric we call mu, combining well-known measures of the wellbeing of the state and the individual. The resulting measure of disorder ranges from a high Central African Republic to a low Norway. We then seek to explain the global distribution of mu. We challenge the conventional wisdom that European Colonialism and its 
echoes are the origin of failure in roughly half the world's nations, and we do so on the strength of a quantitative model that includes two variables missing from previous analysis. These are altitude adjusted monthly mean high temperature, and the historical and contemporary presence of a family law that allows for, or even encourages, polygamy's the taking of multiple wives by some men, creating a chronic scarcity of marriageable women, and engendering violence and the breakdown of trust.

Ann McCants, MIT, and Dan Seligson, Independent Scholar

\section{Negative Shocks and Mass Persecutions: Evidence from the Black Death}

We study the Black Death (1347-52) pogroms to shed light on the economic and non-economic factors determining when a minority group will face persecution. In theory, negative shocks increase the likelihood that minorities are persecuted. But, as shocks become more severe, the persecution probability decreases if there are economic complementarities between majority and minority groups. The effects of shocks on persecutions are thus ambiguous. We compile city-level data on Black Death mortality and Jewish persecutions. At an aggregate level, scapegoating increases the probability of a persecution. However, cities which experienced higher plague mortality rates were less likely to persecute. Furthermore, for a given mortality shock, persecutions were less likely in cities where Jews played an important economic role and more likely in cities where people were more inclined to believe conspiracy theories that blamed the Jews for the plague.

REMI JEDWAB, George Washington University, Noel Johnson and Mark Koyama, George Mason University

\section{SESSION 7: DISASTER STRUCK}

How the Horsemen of the Apocalypse Interact: The Relationship between Warfare, Epidemic Diseases and Mortality in the Seventeenth-Century Low Countries

Recurring periods of warfare and outbreaks of epidemic disease are often invoked as determinants for early modern European economic development, albeit with a variety of conflicting explanations on their role. Current empirical evidence relies heavily on local case studies or inference from low resolution macro data, resulting in a paucity of systematic evidence. In this paper, we focus on the impact of warfare and epidemic disease on mortality patterns throughout the seventeenth-century Low Countries. Using a new dataset of burials for 415 localities combined with a detailed reconstruction of recurring warfare in the region, we test the spatial and chronological links between the three. We provide evidence on the long-standing notion that warfare facilitated the 
spread of epidemics, documenting a spatially uneven spread of raised mortality relative to war. Furthermore, we analyze these patterns between urban and rural settlements, across different episodes of wars, and across political units.

Daniel Curtis, Leiden University, and Bram van Besouw, Utrecht University

When Birth or Death Hits Home: Demography, Growth and the Housing Market in Paris and Amsterdam, 1400-Present

Fueled by economic growth, rising urbanization and population aging are two of the most important trends affecting global society, with important implications for urban housing markets. To understand these, this paper exploits more than 500 years of data on demographics, rent prices and house prices from Paris and Amsterdam. Demographic shocks were common in history, and as modern demographic shifts tend to be slow, very long time series are needed to examine their effects. We show that baby booms positively predict future rent and house prices, while fertility $(+)$, mortality (-) and net migration $(+)$ are related to current prices. Price effects are particularly strong when cities are in decline, consistent with models of durable housing. Some of these effects go beyond housing demand: we argue rent prices proxy for local economic conditions, and propose to use these to test the historical relation between urban economic growth and demographics. We find that rent prices provide strong support for the existence of Malthusian checks before the twentieth century, while urban wage estimates do not.

Marc Francke, University of Amsterdam, and Matthis KorevaAR, Maastricht University

\section{Managing the Food Shocks of the Great Transition: Flemish Cities and the Food Crises of the Fourteenth Century}

Recent research once again framed the fourteenth century as the century of environmental shocks and systemic transitions. This paper will focus on the rapid succession of urban food shocks before, during and after the 1348 Black Death. The major Flemish Cities provide a unique context to investigate the origins, the impact and the consequences of the Great Shocks of the fourteenth century. Based on new and exciting price series for the major cities of Bruges, Lille, Douai and Cambrai, we will not only be able to reconstruct divergences in the impact of the food shocks of the fourteenth century, but also to question the role of large urban landowners in the management and production of these food crises. In order to do so, we aim to compare the grain economy of urban hospitals and ecclesiastical institutions in a period of relative price stability before the Black Death (1330-1338) on the one hand and periods of price instability and food shocks both before (1339-1342) and after (1350-54; 1360-61) the Black Death, 
on the other hand. Such enquiry will allow a better understanding of both the causal mechanisms behind these food crises and the way major urban institutions handled and sometimes co-produced these crises.

Stef Espeel, University of Antwerp, and Tim Soens, University of Antwerp

SESSION 8: FIRMS AND PRODUCTIVITY

\section{What Were the Effects of the Introduction of Corporate Taxes in Nazi-Occupied Netherlands?}

We exploit a major overhaul in the Dutch corporate tax code during the Second World War to shed new light on the effects of corporate taxes on firm policies and valuations. Whereas before the occupation, corporate profits were not taxed at all, this changed due to a series of tax rulings, culminating in the 1942 introduction of the corporate tax oevennootschapsbelasting. Using data from primary sources covering the majority of listed firms, we study the effects of this new tax. Three effects of the introduction of the corporate tax are of particular interest to us. First, what was its short term effect on firm value? Second, what was the effect of the corporate tax on firms' financial and accounting strategies? Third, to what extent did the corporate tax and related measures induce the smaller limited liability corporations to change their legal form?

Bert Kramer, University of Groningen, ABe DE Jong, Erasmus University and University of Groningen, and PHILIP FLIERS, Utrecht University

Short- and Long-Run Impacts of Environmental Regulations on Firm Productivity: Evidence from the U.S. Electricity Sector, 1938-1999

Environmental regulations have been shown to generate economic inefficiencies in a variety of contexts. However, little is known about whether such inefficiencies persist in the long run once firms and technology have had a chance to adjust. This paper examines the short- and long-run productivity costs of the Clean Air Act regulations. Using newly digitized data on U.S. fossil fuel fired power plants from 1938-1999, we estimate annual plant-level total factor productivity (TFP), and consider a difference-in-differences approach based on counties moving in and out of compliance with air quality standards. We find that a plant's TFP drops by 8.4 percent on average when the county where this plant is located goes out of compliance, an effect driven by standards for particulate matter. The effect is similar even for plants in counties out of compliance for over 20 years, suggesting they are unable to cost-effectively adjust even in the long run.

Karen Clay and Akshaya Jha, Carnegie Mellon University, Joshua Lewis, University of Montreal, and Edson Severnini, Carnegie Mellon University 


\section{The Impact of Business Cycle Conditions on Firm Dynamics and Composition: Enterprise Entry and Exit in Egypt, 1911-48}

This paper explores firm dynamics by legal form in Egypt between 1911 and 1948 in response to changes in the macroeconomic conditions. I show that partnership entry was procyclical but exit acyclical. Partnerships established during booms were smaller, less likely to grow, and more likely to exit earlier relative to partnerships formed during busts. Corporate entry and exit rates were acyclical; the quality of corporate entry was invariant to the business cycle. The business cycle affected firm dynamics through the extensive margin of entry by selecting firms of different quality. Booms led to the creation of more firms, exclusively drawn from the lower tail of the productivity distribution. This is consistent with a theory of costly entry in the presence of high agency costs in capital markets. Corporations did not exhibit similar patterns due to lower capital costs and much higher barriers to entry and exit.

Cihan Artunc, University of Arizona

\section{SESSION 9: HUNGRY MASSES REVOLT}

\section{Grain Prices, Social Conflicts, and Public Goods Provision in Eighteenth-Century China}

Famine relief smoothed food supply and reduced the risks of social instability in premodern societies. China had both public and private famine relief during the eighteenth century. This paper quantitatively examines which type of relief was more effective. We construct a panel dataset from 1742 to 1795 by combining the high quality grain price series, weather conditions, local conflicts, official storage, and measures for local elites. Using the response of social conflicts to fluctuations in grain prices, we find that, although the increase in grain prices led to more social conflicts nationwide, it was not the case in some regions. We then use grain storage in the official system and indicators for local elites to capture the provision of public and private famine relief, separately. We find that different forces mattered in different regions. In North China, official granary was the predominant factor; while in Lower Yangzi, the local elites played a more important role.

Cong Liu, Shanghai University of Finance and Economics, and $\mathrm{SE}_{\mathrm{E}} \mathrm{YN}$, Peking University

\section{Extreme Poverty and a Culture of Violence}

The impact of extreme poverty on the development of a culture of violence. During a cooling period of 1580-1650, severe drought led to extreme poverty in China. To estimate the long-run impact of extreme poverty, I construct a continuous treatment in 
exposure to extreme poverty: years under severe drought between 1580 and 1650. First, I establish a positive relationship between years under severe drought and incidences of violence between 1580-1650. Then I show that the relationship continued to exist for subsequent periods. Third, using modern-day court cases, I uncover a positive relationship between years under severe drought between 1580 and 1650, and the number of bodily injury cases between 2010 and 2017. One of the key innovations of this paper is to account for pre-existing cultural characteristics supportive of violence. In addition, I show that text analysis is a powerful tool for extracting information from historical records.

Melanie Xue, Northwestern University

\section{The Deep Roots of Rebellion: Evidence from the Irish Revolution}

This paper studies how cultural norms shaped by negative historical shocks can explain conflicts in the long-run. Exploiting a unique dataset constructed from historical archives, we test whether the Irish amine (1845-1850), one of the most lethal starvation in history, changed political attitudes and contributed to the Irish Revolution (1913-1921). First, we investigate the determinants of joining the rebellion movement on the basis of the 1911 Irish Census and the official lists of rebels. We find that rebels are more likely to be male, young, catholic and literate. Second, we explore whether the famine played a role in the probability of joining rebellion activities. Controlling for the level of economic development and other potential concurring factors, we provide evidence in support of the famine's inter-generational legacy of rebellion.

Gaia Narciso, Trinity College Dublin, and Battista Severgnini, Copenhagen Business School

\section{SESSION 10: (UN) INTENDED CONSEQUENCES OF INFRASTRUCTURE}

\section{The Interstate Highway System and the Development of the American Economy}

We study the aggregate and distributional welfare impacts of the Interstate Highway System (IHS) between 1960 and 2010. To understand the impacts of the IHS, we estimate the general equilibrium trade model proposed by Donaldson and Hornbeck (2016). To construct our measure of market access, we digitize various editions of Rand McNally's auto atlas for each decade 1960-1990, and then merge these data with modern shapefiles maintained by the federal government. We find that the roll out had large aggregate impacts on the nation, with the South and West experiencing the largest increases in market access. Importantly, we demonstrate which segments of the IHS are most valuable to the nation. 
On the Right Track: Railroads, Mobility, and Innovation During Two Centuries

We study the construction of the nineteenth-century Swedish railroad network and estimate its effects on innovation during two centuries. To address endogenous placement of the network, our analysis exploits the fact that the main trunk lines were built with the overarching aim to connect particular city centers, while at the same time considering construction costs. Estimates show that innovative activities increased substantially in areas traversed by the railroads: the number of active innovators increased and the average innovator became more productive. Exploring the effects on knowledge diffusion across space, our analysis shows that innovators residing in areas connected by the railroad start to collaborate more and over longer distances, especially with other innovators located along the railroad network. Finally, we show that the differences in innovative activities were intensified over the twentieth century. Areas traversed by the historical railroads exhibit much higher rates of innovation today.

DAvid Andersson, Uppsala University, THOr Berger, Lund University, and Erik Prawitz, Research Institute of Industrial Economics, Stockholm

Transportation and Health in a Developing Country the United States, 1820-1847

I study the impact of transportation on health in the rural United States, 1820-1847. Measuring health by average stature and using within-county panel analysis and a straight-line instrument, I find that greater transportation linkage, as measured by market access, in a cohort's county-year of birth had an adverse impact on its health. A one-standard deviation increase in market access reduced average stature by 0.10 to 0.29 inches. These results explain 26 to 65 percent of the decline in average stature in the study period. I find evidence that transportation affected health by increasing population density, leading to a worse epidemiological environment.

Ariell ZimRan, Vanderbilt University

SESSION 11: SOCIETAL RESPONSE TO CONFLICT

\section{Historical Warfare and Long-Run Development in India}

This paper analyzes the relationship between historical warfare and long-run development in India. We identify the specific locations of more than 500 conflicts on the Indian subcontinent prior to European colonialization. To the best of our knowledge, this database represents the first attempt to geocode all such conflict locations. We use this database to construct estimates of local exposure to pre-colonial warfare. We document a positive and significant relationship between pre-colonial conflict exposure and modern economic development levels across Indian districts. Furthermore, we show 
that greater pre-colonial conflict exposure predicts a significant reduction in modern violence levels. To explain such results, we draw on the logic of "war makes states, and states make peace" (Morris 2014). Overall, our analysis has implications for three major debates. First, how relevant is the "war makes states" argument beyond Europe? Second, do pre-colonial events influence modern development patterns within India? Finally, what are the fundamental determinants of cross-regional economic differences today?

\author{
Mark Dincecco, University of Michigan, \\ JAMES FensKe, University of Warwick, \\ Anil Menon, University of Michigan, \\ and Shivaji MukHerJee, University of Toronto
}

\title{
All Along the Watchtower: Linear Defenses and the Introduction of Serfdom in Russia
}

Why did Russia enserf its previously free peasants, just as Western Europe was undergoing the opposite transition? Domar argued that Russia's low population density would have resulted in a high equilibrium wage, and therefore created the incentives for the nobility to restrict labor mobility, so as to appropriate the agricultural surplus. However, while this explains the cross-sectional pattern, it cannot explain why serfdom was not reintroduced in the west after the Black Death. In this paper I propose a new theory, that argues that serfdom was necessary to ensure that the defense cordon against the Tatar slave raids from the south could be effectively manned. In support of my theory I demonstrate a geographic association between serfdom and the sequence of linear defenses employed. I also deploy spatial methods to calculate the optimal invasion routes for Tatars, as well as the optimal defense lines to block the raids. I find that modern patterns of development are significantly correlated with calculated defense lines towards the South, where nomadic raids made the cordon defense necessary, but not towards the West, where invaders had extensive logistical tails and could be effectively parried by blocking only the major roads.

Andrea Matranga, New Economic School

\section{The Role of the Marshall Plan in the Italian Post-WWII Recovery}

We study the effects of international aid through the Marshall Plan on Italian postWWII recovery. We identify the causal effects by exploiting the fact that between 1943 and 1945, bombings in Italy were aimed to block the German escape from Southern Italy to Germany. We compare counties that, although similar before WWII, were differently bombed during WWII and, therefore, received a different amount of U.S. aid. We find 
that the number of industrial firms increased by 17 percent in counties that received a higher portion of U.S. aid; this effect is largely driven by small firms; the productivity of the agricultural sector increased, while the number of employees decreased; provinces in the top quintile of the bombing distribution experienced a quicker and larger economic expansion

Michela Giorcelli, UCLA, and Nicola Bianchi, Northwestern University

\section{SESSION 12: ECONOMICS OF THE FAMILY}

\section{Marrying for Money: Evidence from the First Wave of Married Women's Property Laws in the United States}

Marriage may substitute for formal business contracts, especially in environments with limited contract laws, by facilitating the efficient organization of labor and capital. We explore the pooling of capital as a motive for marriage. We measure the impact of married women's property acts introduced in the American South during the 1840s on assortative matching in the marriage market. These laws did not allocate property rights to women; they merely shielded their property from seizure by husbands' creditors. This mitigated downside risk while limiting the family's access to collateral. Using database of marriage and census records, we show that these laws were associated with an overall increase in assortative mating, suggesting that the ability to pool capital importantly contributed to the gains from marriage. In addition, there is considerable heterogeneity in the effect in different regions of the joint men's and women's wealth distribution. We provide an interpretation for these results.

Laura Salisbury, York University, and Peter Koudiss, Stanford University

\section{Harmattan Winds, Disease and Gender Gaps in Human Capital Investment}

This paper examines whether disease burdens, especially prevalent in the tropics, contribute significantly to widening gender gaps in educational attainments. We estimate the impact of sudden exposure to the 1986 meningitis epidemic in Niger on girls' education relative to boys. Our results suggest that increases in meningitis cases during epidemic years significantly reduce years of education disproportionately for schoolaged going girls in areas with higher meningitis exposure. There is no significant effect for boys in the same cohort and no effects of meningitis exposure for non-epidemic years. We highlight income effects of epidemics on households and early marriage of girls in areas with higher exposure during epidemic years. We also use National 
Aeronautics and Space Administration (NASA) data to investigate the relationship between climate variables and the meningitis epidemic and explore how climate change could potentially worsen social inequality through widening the gender gap in human capital investment.

Belinda Archibong, Columbia University

\section{Income Pooling as a Household Risk-Reduction Strategy: Evidence for Mid-Twentieth Century Britain}

Household income-pooling has long been recognized as an important strategy for reducing the severe risks associated with "crises" in individual incomes from illness, unemployment, and other adversities. However, both the extent of income-pooling and the factors influencing individuals' access to the income pool are generally opaque to direct investigation, as virtually all historical household expenditure surveys do not identify both the incomes and expenditures of each family member. We utilize almost 13,000 newly-digitized original schedules for the 1953/54 British Household Expenditure Survey (which, uniquely among British family expenditure surveys, contains information on income and expenditure for individual household members), to examine a number of key issues highlighted in the working class family economy literature. These include the impacts of age, gender, and formal labor force participation on access to the household income pool, together with the influence of total household income, socio-economic status, and regional factors.

Ian Gazeley and Andrew Newell, University of Sussex, Peter Scott and James Walker, University of Reading

\section{SESSION 13: SOCIAL MOBILITY IN THE US}

\section{Did Great Migration Destinations become Mobility Traps?}

Upward mobility rates in U.S. locations are strongly negatively correlated with the black population share. However, family sorting and a lack of experimental variation in racial shares poses a dual challenge to identifying a causal mechanism. I leverage a large scale historical natural experiment to overcome these challenges: the mass movement of African Americans from the rural South to northern cities from 1940 to 1970 during the Great Migration. I use idiosyncrasies in early migrants' location choices and southern economic changes during this period to construct shocks to the black population share in northern cities. Combining these shocks with measures of contemporary neighborhood effects, I show that two thirds of the relationship between the migration and mobility can be attributed to the causal effect 
and one third to composition and selection. Persistently higher racial segregation and private school enrollment in these areas imply local public goods are a mediating factor.

Ellora Derenoncourt, Harvard University

A Different Land of Opportunity: The Geography of Intergenerational Mobility in the Early 20th-Century US

There is substantial variation in intergenerational mobility across the United States today, with the non-industrial Midwest exhibiting some of highest levels of upward mobility. Has the landscape of mobility always been this way? Constructing a large historical linked sample across the 1910 and 1940 censuses, I show that the geography of intergenerational mobility was substantially different in the early twentieth century, during which the coastal areas and the industrial Midwest were the most upwardly mobile regions. To explain the differences between the two periods, one needs to know what shaped the spatial patterns of mobility in the past. Exploiting variation in the ages at which children moved across states, I show that neighborhoods in the early twentieth century had substantial childhood exposure effects on grade-for-age status but the effects on adult income ranks are not robust, in contrast to the present. Childhood environment is thus unlikely to be the key driver of the historical patterns of upward mobility. The composition of jobs in local labor markets, on the other hand, may have had an important role to play. I provide evidence that the local labor market structure had a causal effect on individual outcomes by comparing the outcomes and locations of brothers, and by using variation in past migration patterns induced by railroad networks. Over time, childhood environment became a relatively more important determinant of upward mobility, which could provide one explanation for the shift in the landscape of intergenerational mobility.

Hui Ren Tan, Boston University

\section{The Aftermath of Policy Failures: The Southern Homestead Act and the Freedmen's Saving Bank in Florida}

Reconstruction provides fertile ground for examining the impact of failed policies on their intended recipients. The Sothern Homestead Act provided a route to land ownership for former slaves and is largely regarded as a failure. The Freedmen's Bank provided banking services to former slaves before its collapse in 1874. The state of Florida provides a unique opportunity to evaluate the impact of these failed policies. I have collected records for all successful SHA homesteaders, a relatively complete sample of failed homesteaders, the depositor records for the Freedmen's Bank in Tallahassee, the index to depositors in Jacksonville, and the entirety of 1880 agricultural 
census for the state. I have linked these to the pre-existing 100 percent IPUMS sample of Florida in 1880. With these records, the African-American population can be divided into five categories: successful homesteaders, failed homesteaders, those who never homesteaded, Freedmen's bank account holders, and non-bank account holders

Melinda Miller, Virginia Tech

\section{SESSION 14: CITY GROWTH}

\section{The Dynamics of City Population Growth: Evidence from Historical Tornadoes}

We study the impact of destructive shocks on city population growth using the (truly) natural experiments of tornadoes in the United States during the nineteenth and early twentieth century. We employ a treatment-control framework with towns that are close but not hit by the tornado serving as the control group. This method allows us to control for local fundamentals, one possible explanation for differences in levels and trends in city populations. We find persistent negative effects on the relative population growth rates of towns affected by tornadoes on the order of 0.5 percent per year showing little signs of dissipating at least over our period of study. This effect is inconsistent with a random walk model of city population growth or models that are mainly driven by local fundamentals.

Chris Vickers, Auburn University, and Nicolas Ziebarth, Auburn University

\section{Can Kings Create Towns That Thrive? The Long-Run Implications of New Town Foundations}

This paper asks two fundamental questions: (i) Can urbanization cause agricultural growth? and (ii) Can place-based policies drive urbanization even in suboptimal locations? We analyze the historical experiment of new town foundations between 1570 and 1810 in Sweden. Running difference-in-difference regressions on 2,218 geocoded parishes measured at 60 year intervals, we compare parishes that change distance to the closest town with parishes that remain unaffected by new towns. New towns created scope for extensive growth, but no significant effect in terms of intensive growth. Towns were founded in sub-optimal locations in terms of the agricultural potential of their local hinterland and remained hardly larger than comparable rural parishes until the onset of the Industrial Revolution. Nevertheless, founded towns persist until today. We argue that the persistence in urban growth is neither related to first nor second nature geography. Instead sunk-investments in infrastructure helped the alleviation of spatial coordination failures. 


\section{Public Health Efforts and the Decline in Urban Mortality}

Using data on 25 major American cities for the period 1900-1940, we explore the effects of municipal-level public health efforts that were viewed as critical in the fight against food- and water-borne diseases. In addition to studying interventions such as treating sewage and setting strict bacteriological standards for milk, which have received little attention in the literature, we provide new evidence on the effects of water filtration and chlorination, extending the work of previous scholars. Contrary to the consensus view, we find that none of the interventions under study contributed substantially to the observed declines in total and infant mortality.

D. Mark Anderson, Montana State University, Kerwin Charles, University of Chicago, and Daniel I. ReEs, University of Colorado Denver

\section{SESSION 15: CAUSES AND CONSEQUENCES OF FAMINES}

\section{The Political Economy of Famine: The Ukrainian Famine of 1933}

The famine of 1932-1933 in Ukraine killed as many as 2.6 million people out of a population of approximately 30 million. Three main explanations have been offered: negative weather shock, poor economic policies, and genocide. This paper uses variation in exposure to poor government policies and in ethnic composition within Ukraine to study the impact of policies on mortality, and the relationship between ethnic composition and mortality. It documents that (1) the data do not support the negative weather shock explanation: 1931 and 1932 weather predicts harvest roughly equal to the 1925-1929 average; (2) bad government policies (collectivization and the lack of favored industries) significantly increased mortality; (3) collectivization increased mortality due to drop in production on collective farms and not due to over extraction from collectives (although the evidence is indirect); (4) back-of-the-envelope calculations show that collectivization explains at least 31 percent of excess deaths; (5) ethnic Ukrainians seem more likely to die, even after controlling for exposure to poor Soviet economic policies; (6) Ukrainians were more exposed to policies that later led to mortality (collectivization and the lack of favored industries); (7) enforcement of government policies did not vary with ethnic composition (e.g., there is no evidence that collectivization was enforced more harshly on Ukrainians). These results provide several important takeaways. Most importantly, the evidence is consistent with both sides of the debate (economic policies vs genocide). (1) backs those arguing that the famine was man-made. (2)-(4) support those who argue that mortality was due to bad policy. (5) is consistent with those who argue that ethnic Ukrainians were targeted. For (6) and (7) to support genocide, it has to be the case that Stalin had the foresight that his policies would fail and lead to famine mortality years after they were introduced (and therefore disproportionately exposed Ukrainians to them). 


\section{Scarring and Selection in the Great Irish Famine}

What impact do famines have on survivors? We use a population exposed to severe famine conditions during infancy to document two opposing effects. The first: exposure leads to poor health into adulthood, a scarring effect. The second: survivors do not themselves suffer health consequences, a selection effect. Anthropometric evidence on over 21,000 subjects born before, during and after the Great Irish Famine (1845-52), among modern history's most severe famines, suggests selection is strongest where mortality is highest. Individuals born in heavily-affected areas experienced no measurable stunted growth, while scarring was found only among those born where excess mortality was low.

Matthias Blum, Queen's University Belfast,

Chris Colvin, Queen's University Belfast, and Eorn McLaughtin, University of St. Andrews

The Rise and Fall of the Know-Nothing Party

During the 1850s, the nativist and staunchly anti-Catholic Know-Nothing Party emerged as a dominant force in Massachusetts politics. Using newly digitized archival annual town-level vote counts in Massachusetts and federal and state census data from 1850-1870, we look at the causes and consequences of the Know-Nothing party's rapid rise to power. Our first aim is descriptive: to understand where Know-Nothing support was strongest and examine how they lost their advantage. In 1855, the Know-Nothings won almost every seat in the General Court as well as the governorship. Yet this success was short-lived and their area of ardent support consolidated on the coast. To examine the rise of the party, we will construct a share-shift instrument based on the occupational composition of native-born men prior to the Know-Nothing ascent and the growth over time of Irish male labor into traditionally native-born occupations. Our second aim in future work is to causally identify the effects of the Know-Nothings on the health and socioeconomic outcomes of the Irish. Preliminary results suggest that the rise of the Know-Nothing Party is predicted by economic factors, but that the decline was smallest in places with a larger amount of Irish immigration conditional on economic changes.

Marcella Alsan, Stanford University, Katherine ERIKSSON, UC Davis, and Greg Niemesh, Miami University

\section{SESSION 16: LASTING EFFECTS OF POLICIES}

Mistrust in Medicine: The Legacy of Colonial Medical Campaigns in Central Africa

Between 1921 and 1956, French colonial governments organized medical campaigns to treat and prevent sleeping sickness. Villagers were forcibly examined and injected with medications with severe, sometimes fatal, side effects. We digitized thirty years of 
archival records to document the locations of campaign visits at a granular geographic level for five central African countries. We find that greater historical exposure to the campaigns reduces trust in medicine- measured by willingness to consent to a free, non-invasive blood test. The resulting mistrust is specific to the medical sector. We examine relevance for present day health initiatives; we find that World Bank projects in the health sector are less successful in areas with greater exposure to the campaigns.

Sara Lowes, Bocconi University, and Eduardo Montero, Harvard University

\section{Market Frictions, Health, and Development: The Effect of The United Mine Workers of America's Health Programs in 1950s Appalachia}

Beginning in 1950, the United Mine Workers of America (UMWA) started providing free health insurance to coal miners and their families and, in 1956, completed ten stateof-the-art hospitals in Appalachia. We use a difference-in-differences approach with annual county-level data to estimate separately the impact of the insurance from the new hospitals. Our findings suggest that the UMWA insurance increased demand; the number of babies delivered in a hospital increased by 5 percent for the average county. Consistent with market frictions or supply side rigidities limiting the effectiveness of demand side interventions in poor rural areas, however, we find no increase in supply of hospital beds or medical professionals until the UMWA built its own facilities. These results provide new evidence that market frictions or supply side rigidities more typical of developing countries can limit the effectiveness of health care programs in regional pockets of rural poverty in developed countries, too.

Theodore Figinski and Erin Troland, U.S. Treasury

\section{The Long-Term Impact of Italian Colonial Roads in the Horn of Africa, 1935-2000}

Between 1935 and 1940 the Italians built an extensive road network to facilitate the occupation of Ethiopia and secure control over the Horn of Africa, but were expelled in 1941. This provides a unique case study to examine the long-run effect of cheap transport networks on the concentration of economic activity in developing countries. The results show that cells located next to Italian paved roads are significantly richer today and that the relationship is causal. Persistence is explained by a combination of direct and indirect mechanisms: colonial roads attracted economic activity through lower transport costs until 1960. After that date, the advantage of treated locations persisted only indirectly through increasing returns to scale. 